\title{
Antecedents of Job Stress and its impact on Job Performance and Job Satisfaction
}

\author{
Muhammad Rizwan \\ Lecturer, Department of Management Sciences \\ The Islamia University of Bahawalpur, Pakistan \\ E-mail: rizwan.arshad@iub.edu.pk
}

Arooba Waseem

Research scholar, Department of management sciences

The Islamia University of Bahawalpur, Pakistan

Syeda Anam Bukhari

Research scholar, Department of management sciences

The Islamia University of Bahawalpur, Pakistan

DOI:10.5296/ ijld.v4i2.6097 URL: http://dx.doi.org/10.5296/ ijld.v4i2.6097

\begin{abstract}
To achieve the pleasures of successful work place is an art of coping with stress. Job stress is a very important issue in this new era. So, this research is emphasized the root causes of job stress like role conflict role ambiguity and identifies its effects on job satisfaction and job performance. From several organizations, a self-administered questionnaire was used for data collection.200 questionnaires were distributed out of which 150 were chosen for more study and suitable sampling method was used for this. SPSS is used for data analysis statistically. The results showed significant positive association of job stress with role conflict, role ambiguity and negative association with job satisfaction. In addition, role ambiguity has a significant positive relation with role conflict. The results also show that there is no significant relation of job stress with job performance. In addition, role ambiguity has significant negative relationship with job satisfaction and the last one role conflict has no significance relation with job satisfaction. For better understanding of behavior and comfort of the employees, the results of the study can be helpful. For future recommendations, this research suggests the guidelines more concisely and briefly.
\end{abstract}

Keywords: Job stress, job performance, job satisfaction, role conflict, role ambiguity 


\section{Introduction}

The term "stress" comes from physics and was transferred into psychology. The term stress shows the relation between the person and the environment. While term " job stress" can be defined as an employee's awareness or feeling of personal dysfunction as a result of apparent conditions or activities in the workplace, and the employee's psychological and physiological reactions caused by these uncomfortable, unwanted, or threats in the employee's instant workplace environment. In the past research, job stress has received significant attention. Job stress is different from general stress as it is organization and job related and it is also greatly an individual reaction.

For researchers and practitioners, stress in the workplace has been of growing concern. Stress may express itself differently, and affect workers differently, in different work contexts. It is also a well-known phenomenon or process at work. In 1997, Faulkner and Patiar said the workplace may be a major source of stress for individuals considering the amount of time that is spent and the fact that financial security and career success are dependent on work performance. In past organization behavior research, job stress, and job performance have received extensive attention. To a company's overall performance, these organizational behavior variables are important.

In the work place, job stress is defined as the unfocused negative response of the body to demands. Job stress can be led to injury and even poor health. It has different modes of effects, different modes of expressions in different modes of contexts. As psychologically and physically, the effects of stress contribute some harmful implication for workers. Stress can be helpful in better immune system, creativity, problem solving and beneficial to achieve targets. From negative point of view, it may reduce job performance and lot of related effects. It is also examined that job stress has a strong effect on job satisfaction. With lower level of job satisfaction higher level of stress is directly related and vice versa.

Stress is a condition which occurs when individuals realize that the requirements or pressures facing them may be more than they can handle. Stress can affect all aspects of an individual's life and may stem from any number of stimuli. At work, stress may be an awareness indicated by ambiguity, conflict, or overload arising from the work environment and the characteristics of the individual.

There are two types of stress, eustress and distress. Eustress is not necessarily negative. It may help initiate goal-striving. Distress is a condition which occurs when an individual perceives a loss, challenge, or risk. The results are harmful to the organization and the worker when stress levels exceed the resources available to an individual and coping ability.

In the area of job stress, Kahn and Byosiere (1992) concluded that there is very little experimental proof to suggest moderating effects may or may not exist and that the organizational research has not been adequately concerned with organizational and interpersonal factors that might serve as moderators, buffers, or even as antidotes to stress. However, Montgomery et al. (1996) see severe job stress as dysfunctional and decreasing commitment and productivity. Studying job stress in different context tells how to minimize 
its negative effects on worker productivity and job satisfaction and will emphasize to deeper understanding of the phenomenon acts as a whole.

Moreover, some variables that we are going to study in this are role conflict, role ambiguity, job satisfaction and job performance. These variables are positively or negatively related to job stress. As a whole, job satisfaction is the match between an individual's hope and the perceived quality of the job. Role ambiguity is the degree of uncertainty associated with one's performance and the extent to which an individual is unclear about the expectations of others. Role conflict can be defined as an incongruity in communicated expectations that impose on perceived role performance. A typical role conflict scenario occurs when the requests of a customer and supervisor are incompatible.

Job performance involves a quality and quantity of outcomes from individual or group effort attainment. Robbins described job performance as the amount of effort an individual will exert in his or her job. Moreover, the real meaning of job performance relies on "the beliefs in the organization about which behaviors are most valued and the demands of the job, the goals and missions of the organization". These all variables play a key role and help us to understand this topic fully.

\section{Literature review}

\section{Job stress}

According to Montgomery et al.,1996 Job stress can be explained as an employee's awareness or feeling of impaired functioning in the result of perceived conditions or happenings at workplace, and psychological and physiological response of employee's which caused due to bumpy, unwanted, or fear in the workplace environment. At another place he said job stress is an individual's response and too much different from general stress.

Stress is a term useful for different psychological and physiological burdens, which people feels in life. This is the difference between the work demand and employees capability to fulfill these demands. It can be positive as well as negative.

Human resources give knowledge about an individual who have a tendency to fight back external resources acting upon them (Hobful, 1989). In 1997, Keinan said that the idea of stress is wide ranging but still debatable and explained in numerous ways. According to Kahn and Boysiere, (1992) job stress understands as frequent themes role ambiguity, role conflict and the work burden. These issues show negative consequences for workers. By Eckles, 1987 this may cause mental illness and prolonged diseases like heart disease, hopelessness or other evils like drug abuse by Patton, 1988 and intoxication by Patton and Questeel, 1988; Scanlon, 1986.

\section{Role conflict}

Role conflict relates with mismatched role potentials. Conflicts are nothing except Conceptual differences among the employees and higher authority related to tasks and activities and workplace. According to Kahn and Byosier, 1992 stress cause conflict, the assurance to a number of supervisors against the individual's necessities. Rizzo et al. (1970) 
describe role conflict as unsuitability in interconnected potentials that impose on apparent job performance. A distinctive role conflict situation arises when the requests of a customer and supervisor are mismatched. It is suggested by the researchers that to avoid role conflict, organization should be operated agreeing to the theory of classic organizational principle of unity of command that is the employee should be overseen by a single superior and word as a single proposal.

Employee with lack of experience and knowledge feels more conflict related to job as he is not clear about his duties. Fisher and Gittleson, 1983; Johnston et al., 1990a; Netemeyer et al., 1990; Sager, 1994, according to their researches there is positive and direct relation between job stress and role conflict. It arises when employees have challenged with inadequate task. Role conflict makes the employee incompatible to complete well his or her job task and this causes job stress. Highrole conflict leads to high job stress and vice versa. So, we develop H1 from this:

\section{H1: Higher the role conflict, higher the job stress}

\section{Role ambiguity}

Role ambiguity has stated the uncertainty that is to be expected when unclear role expectations due to lack of information about the role and the work it involves. Bheer and Bhagat (1985) said that the employees are unaware about where to direct their struggles, where to add furthermore, whether his supervisor will clean the performance results as failure or a success. Role ambiguity can be defined as employee who doesn't have clear direction to the expectations of his role in the organization (Rizzo et al., 1970).

Role ambiguity arises when an employee is not clear about task and also not clear about the expectations related to that task, it is a generally accepted concept. Individuals have to face the problem of incomplete information about their duty. Therefore, it is difficult to provide training about a specific situation. This little information availability causes the uncertainty about expectations related to the particular role. If the role is not clear situation will become very stressful. Due to this worker feels lack of control of that task and this generates greater stress in them. So the role ambiguity has also significant aspect to influence job stress.

\section{H2: Higher the role ambiguity, higher the jobs stress.}

\section{Role ambiguity to role conflict}

Sagar(1994), based on a fusion of previous research, proposeda positive relationship between role ambiguity and role conflict, but there is weak relationships have been found between ambiguity and job satisfaction. The basic logic is that ambiguity in the job will lead to the perception of role conflict by the individual. An empirical support for the ambiguity and conflict relationship is provided by Brown and Peterson (1993).

\section{H3: Higher the role ambiguity, higher the role conflict.}




\section{Job Satisfaction}

In 1997, Spector explained job satisfaction as simply how people feel about their jobs and different aspects of their jobs. Job satisfaction speaks of individual feelings about the rewards they have received on the job, Lawler (1990). Many elements of job satisfaction have been recognized in previous research. According to Lankauand Scandura(2002) and Lefkowitz(1994), they include organizational reward systems, factors such as power distribution and control, and individual differences such as self-esteem and the need for achievement.

Sager's outcomes put forward that role conflict directly effects job stress and job satisfaction while job satisfaction seems to decrease job stress.

Williams et al., 2001 stated that the underlying impact of job satisfaction and job stress has been hypothesized, Lee and Ashforth, 1993 tested empirically, and Sullivan and Bhagat, 1992 subject to meta-analysis. Paraphrased, when workers feel stress on the job, it frequently exhibits itself in negative practices of job displeasure. Reported by Kaliski, (2007) that job satisfaction indicate pleasure and eagerness with one's work and it is the basic element that leads worker to income elevation, acknowledgment and the success of other objectives that leads to a feeling of self-actualization. Therefore, the hypothesis is presented an inverse relationship between stress and job satisfaction as follows

\section{H4: Lower the jobs stress, higher the job satisfaction.}

According to Netemeyer et al., 1990; Teas, 1983, role conflict looks to have a stronger effect on job satisfaction than doe's role ambiguity. Findings of Sager's recommend that role conflict directly impacts job stress and job satisfaction while job satisfaction seems to lessen job stress.Inadding to affecting job stress, role conflict is probable to be a negative influence on job satisfaction and job expectations. Subsequently there is not awide-ranging base of studyrepresenting that ambiguity does not directly influence stress, we hypothesize that ambiguity and conflict each has a direct negative relationship to job satisfaction.

\section{H5: Higher the role conflict, lower the job satisfaction.}

H6: Higher the role ambiguity, lower the job satisfaction.

\section{Job performance}

Job performance is a crucial impression intimate work and administrative insolence. Campbell, 1990 said through the past 10 or 15 years, detectives have made progress in revealing and increasing the performance idea. Porter and Lawler (1968) said that there are 3types of performance. One is the point of productivity possibilities, over a given period of time total of sales, the formation of a bunch of recruit's reportage to manager, and so on. The second type of point of performance holds valuations of persons by an important person other than the person whose performance is being measured. The third type of performance 
measures is self-appraisal and self-ratings. Hersey and Blanchard, 1993 said that job performance calculates the level of success of business and community goals and duties from the viewpoint of the umpiring party. Furthermore, developments have been made in postulating for most forecasters and procedures related with job performance. Job stress is contrary wise related to job performance. Schermerhorn, Hunt \& Osborn, 2005 said that the job performance contains a quantity and quality of results from individual or group struggle completion. In 2005 Robbins defined job performance as the aggregate of power an individual will utilize in his job. Furthermore, in 2003 Befort \& Hattrup said that the spirit of job performance trusts on "the demands of the job, the objectives and tasks of the organization, and views in the organization about which deeds are most treasured". Job stress is frequently realized as dysfunctional in outcome in that it discounts both the quality and quantity of job performance. In 2003 Siu said job stress also wastes the time and energy that an individual devotes distributing with the stressor, restraining focus on the task at hand and thereby distressing performance.

\section{H7: Lower the jobs stress, higher the job performance.}

\section{Research Methodology}

The current research is expressive in its nature. Descriptive research can be illuminated as describing somewhat, some phenomenon or any specific condition. In 1994, Creswell said descriptive researches are those studies that define the prevailing condition in its place of understanding and making decisions. The core goal of the descriptive research is confirmation of the established assumptions that mirror the existing state.

\subsection{Sample/Data}

In order to gather the data for understanding the state about Job stress of personnel in different zones, a sample of 200 respondents will ask to take part in a self-administered questionnaire. The population for the present study is employees in Bahawalpur/Pakistan.

The existing study uses a non-probability sampling method that is convenience sampling. According to Zikmund (1997), convenience sampling is a sampling technique that finds and gathers the related information from the sample or the unit of the study that are appropriately available (Zikmund, 1997). Convenience sampling is normally used for collecting a large number of completed surveys quickly and with economy said by Lymet al., 2010.

\subsection{Instrument and Measures}

The survey instrument of the current study address two major purposes: First is to examine the association of different variables linked to job stress. Second, to gather facts about the different features of the respondents that can be used to know the differences in diverse classes.

The study tool comprises two segments. Segment 1 contains different particular and demographic variables. This section will get the respondent's data about gender, age, income 
and education.

Segment 2 comprises the fundamental variables that are significant in the existing study. These variables include Job Stress, Job Satisfaction, Job Performance, Role Conflict and Role Ambiguity. This section of the study is established based on the past literature and already used questionnaires.

The scales of the study were supported from the earlier works and available educations. The first three variables of the study were job stress, job satisfaction and job performance. Job stress has four items taken from Beehr et al., 2001, job satisfaction has five items and taken from Terry et al,1993 and job performance has three items taken from Bowraet al., 2011. The next variables are role conflict which has six items taken from Rizzo et al. 1970 and role ambiguity has four items taken from Rizzo et al. 1970.

\subsection{Procedure}

The questionnaire was distributed among 200 plaintiffs in Bahawalpur. These respondents are designated founded on the standards overhead stated. Earlier open-handed the questionnaire, the goal of education and queries were clarified to the respondents so they can effortlessly complete the questionnaire through related replies.

\subsection{Reliability Analysis}

All the variables of our questionnaire were reliable as their Cronbach Alpha values were more than acceptable and recommended value 0.50 by Nunnally (1970) and 0.60 by Moss et al. (1998). This shows that all the 22 items were reliable and valid to measure the stress of employees and their daily job.

\section{Table 1: Reliability of measurement instruments}

\begin{tabular}{|l|l|l|}
\hline Scales & Items & Cronbach Alpha \\
\hline Job stress & 4 & 0.841 \\
Job satisfaction & 5 & 0.801 \\
Job performance & 3 & 0.774 \\
Role conflict & 6 & 0.767 \\
Role ambiguity & 4 & 0.784 \\
& & \\
\hline
\end{tabular}




\section{Macrothink \\ International Journal of Learning \& Development \\ ISSN 2164-4063 2014, Vol. 4, No. 2}

\section{Results and Analysis}

\section{Role conflict and Job stress}

According to the result of the study role conflict has a significant positive association with job stress with $\beta=0.401$ and $\mathrm{P}=0.000$ that means the role conflict contributes to more than $40 \%$ to job stress. So we accept the hypothesis 1 .

\section{Role ambiguity and Job stress}

According to the result of the study role ambiguity has a significant positive association with job stress with $\beta=0.153$ and $\mathrm{P}=0.042$ that means the role ambiguity contributes to more than $15 \%$ to job stress. So, we accept the hypothesis 2 .

\section{Role ambiguity and role conflict}

Regression analysis result shows that role ambiguity found significantly related with role conflict. There is a significant positive relationship between role ambiguity and role conflict with $\beta=0.168$ and $\mathrm{P}=0.039$. Hence, we accept the hypothesis 3 .

\section{Job stress and Job satisfaction}

According to the result of the study job stress has a significant negative relationship with job satisfaction with $\beta=-0.281$ and $P=0.001$ that means the job stress contributes more than $28 \%$ to job satisfaction. So, we accept the hypothesis 4 .

\section{Role conflict and Job satisfaction}

While considering the significance between role conflict and job satisfaction, the result of current studies shows no significant relation between these variables with $\beta=-0.032$ and $\mathrm{P}=$ 0.697. So we reject the hypothesis 5.

\section{Role ambiguity and Job satisfaction}

Regression analysis result shows that role ambiguity found significantly related with job satisfaction. There is a significant negative relationship between role ambiguity and job satisfaction with $\beta=0.245$ and $P=0.002$. Hence, we accept the hypothesis 6 .

\section{Job stress and job Performance}

According to the result of the study job stress has no significant relation with job performance with $\beta=-0.075$ and $\mathrm{P}=0.364$ and that means the job stress contributes to more than $7.5 \%$ to job performance. So, we reject the hypothesis 7 . 


\section{Macrothink

Table 4: Regression Results

\begin{tabular}{|c|c|c|c|c|c|c|}
\hline Hypothesis & $\begin{array}{l}\text { Model } \\
\text { variables }\end{array}$ & Estimate & S.E & C.R & Sig & Results \\
\hline H1 & $\begin{array}{l}\mathrm{RC}^{\longrightarrow} \\
\mathrm{JS}\end{array}$ & 0.401 & 0.086 & 5.380 & 0.000 & SUPPORTED \\
\hline $\mathbf{H 2}$ & $\begin{array}{l}\mathrm{RA} \\
\mathrm{JS}\end{array}$ & 0.153 & 0.086 & -2.053 & 0.042 & SUPPORTED \\
\hline H3 & $\begin{array}{l}\mathrm{RA} \longrightarrow \\
\mathrm{RC}\end{array}$ & 0.168 & 0.081 & 2.078 & 0.039 & SUPPORTED \\
\hline H4 & $\begin{array}{l}\mathrm{JS} \\
\mathrm{JS}\end{array}$ & -0.281 & 0.082 & -3.343 & 0.001 & SUPPOERTED \\
\hline H5 & $\begin{array}{l}\mathrm{RC} \longrightarrow \\
\mathrm{JS}\end{array}$ & -0.032 & 0.093 & -0.390 & 0.697 & $\begin{array}{l}\text { NOT } \\
\text { SUPPORTED }\end{array}$ \\
\hline H6 & $\begin{array}{l}\mathrm{RA} \longrightarrow \\
\mathrm{JS}\end{array}$ & 0.245 & 0.087 & 3.177 & 0.002 & SUPPORTED \\
\hline H7 & $\begin{array}{l}\mathrm{JS} \\
\mathrm{JP}\end{array}$ & -0.075 & 0.067 & -0.190 & 0.364 & $\begin{array}{l}\text { NOT } \\
\text { SUPPORTED }\end{array}$ \\
\hline
\end{tabular}




\section{Structural model result}

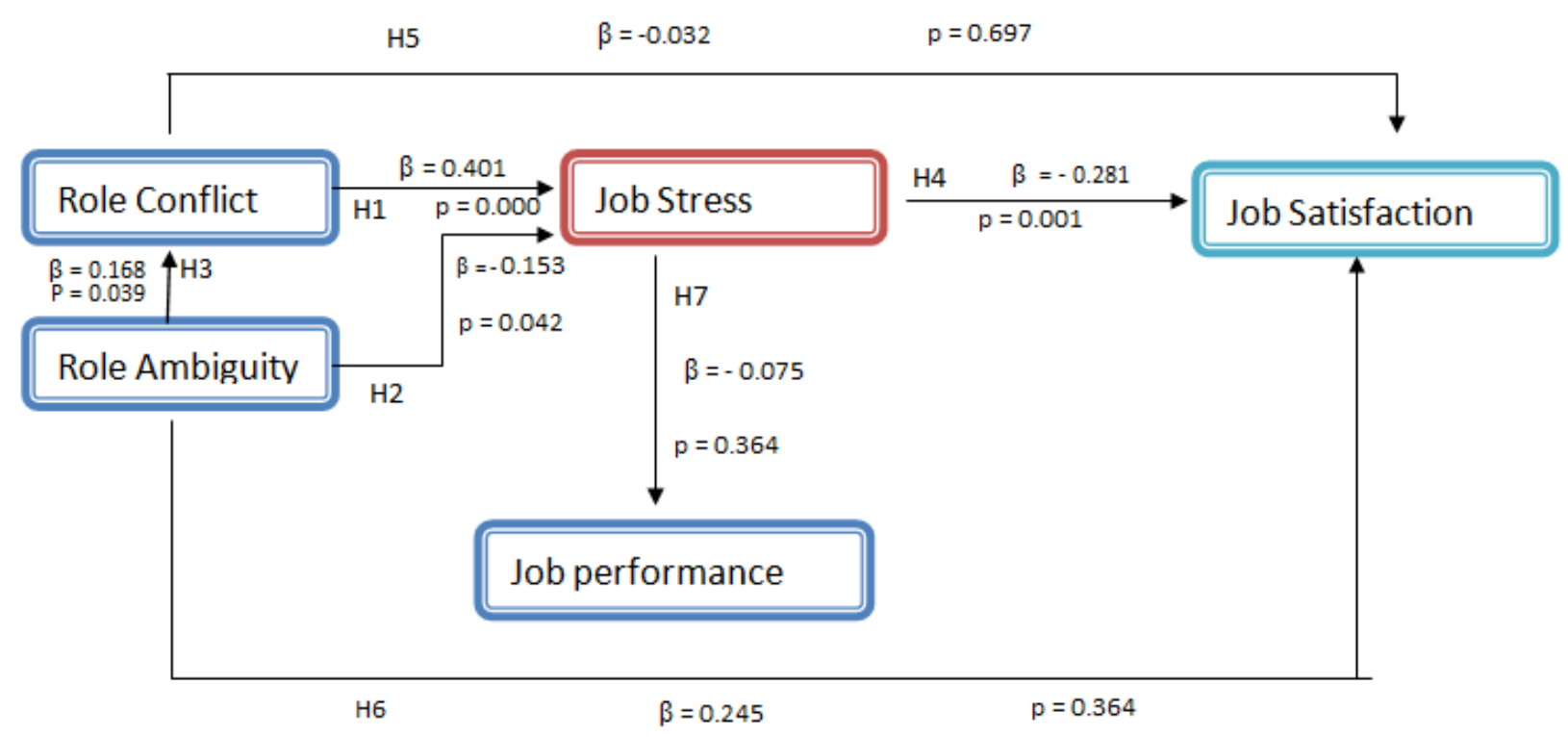

\section{Discussion}

In Bahawalpur, this research has been conducted in the private sector as well as in public sector. To explore the job related stress of people in organizations is the main objective of this research. In this new era of competencies, job stress is a very substantial issue at workplaces So, this research is significantly emphasized on causes and effects of job stress and analyzes its impact upon different variables like job satisfaction, job performance etc. This study also identifies the root causes of job stress like role ambiguity role conflict and their influence on employee's wellbeing, behavior and contribution towards effectiveness. To find the effect of variables on the organizations in Bahawalpur City, we analyze many of past researches and choose the variables from that research papers.

From target population, we conducted this research by taking the sample of 200 employees. 150 of the employees responded to our questionnaire. Our research consists of two parts; in the first part we collect the personal information from employees of different organizations about gender, age, income, education and status. In the second part once we use job stress as dependent variable and role ambiguity, role conflict as independent variables and after that we use job stress as independent variable and job satisfaction and job performance as dependent variables. We conducted analysis on the data collected from the samples. The results show that role conflict has a significant positive relation with job stress and it contributes to more than $40 \%$ to job stress. That means that job stress increases if the employee is not clear about his or her role in any organization. Similarly role ambiguity also has a significant positive association with job stress and it contributes to more than $15 \%$ to job stress. If the employee has not clarity about his or her job then he or she will not be able to perform his or her job well and as a result job stress increases but if he or she will clear 
about everything related to job then stress decreases. In addition regression results show the significant positive relation of role ambiguity with role conflict and it contributes to more than $16.8 \%$ to role conflict. The increase in role ambiguity tends to increase the role conflict and vice versa.

Now, we discuss that job stress has a significant negative relationship with job satisfaction and it contributes to more than $28 \%$ to job satisfaction. The more the job stress the lower the job satisfaction. Employees who have lower job stress in any organizations, they are much satisfied with their jobs and as a result of satisfaction they perform well and benefit their organizations as well. Role conflict contributes to more than $3.2 \%$ to job satisfaction but regression results show that there is no significance relation of role conflict with job satisfaction because the P-value is greater than 0.05.So, we reject this hypothesis. Moreover, regression analysis result shows that role ambiguity found significantly related with job satisfaction. There is a significant negative relationship between role ambiguity and job satisfaction. If the employee is not clear about his or her role then job stress increases and as a result satisfaction decreases and the employee will not be able to perform well. Our last variable is job performance. Results show that there is no significant relationship between job stress and job performance because P-value is greater than 0.05 and hence this hypothesis is rejected.

There is already a large and well established base of empirical research and theory so the issue is not to find new variables and theories to explain employee attitudes and behaviors. Rather it is important to test these conceptualizations across different organizations to assess their validity.

\section{Limitations and Future directions}

The limitation of the study was that this study considered only few factors of job stress like role conflict, role ambiguity, job satisfaction and job performance. The other limitation is that the Sample size of the study is low which should be increased in order to realize the most important determinants at more universal level and the last limitation of this study is that the data is collected from a particular group of people. The research site for our study possibly corresponds more to a high stress rather than a low stress environment. Our study results may be helpful of how such these variables affect the model. To explore this issue more fully, of course replication is needed.

\section{References}

1. Acker, G.M., 2004. The effect of organizational condition (role conflict, role ambiguity, opportunities for professional development, and social support) on job satisfaction and intention to leave among social workers in mental health care.Community Mental Journal 40 (1), 65-73.

2. Adler, N.J., 1983. A typology of management studies involving culture. Journal ofInternational Business Studies 14, 29-47.American Institute of Stress.(2007). Job 
stress.Retrieved from http://www.stress.org/job.htm. Accessed 9/7/09.

3. Anderson, S. E., \& Williams, L. J. (1996). Interpersonal, job, and individual factors related to helping processes at work. Journal of Applied Psychology, 81, 282-296.

4. Agarwal, S. (1993), "Influence of formalization on role stress, organizational commitment, and work alienation of salespersons: a cross-national comparative study", Journal of International Business Studies, Vol. 24 No. 4, pp. 715-40.

5. Anderson, E. and Oliver, R. (1987), "Perspectives on behavior-based versus outcome-based sales force control systems", Journal of Marketing, pp. 76-88.

6. Anderson, J.C. and Gerbing, D.W. (1988), "Structural equation modeling in practice: a review and recommended two-step approach”, Psychological Bulletin, Vol. 103 No. 3, pp. 411-23.

7. Ady, J.C. (1994), "Minimizing threats to the validity of cross-cultural organization research", inWiseman, R.L. and Shuter, R. (Eds), Communicating in Multinational Organizations, Sage,Thousand Oaks, CA, pp. 30-42.

8. Babin, B.J., Boles, J.S., 1998. Employee behavior in a service environment: a modeland test of potential differences between men and women. Journal of Marketing62 (2), 77-91.

9. Beehr, T.A., Drexler Jr., J.A., 1986. Social support, autonomy, and hierarchical level as moderators of the role characteristics-outcome relationship. Journal of OccupationalBehavior 7 (3), 207-214.

10. Behrman, D.N., Perreault, W.D., 1984. A role stress model of the performance and satisfaction of industrial salespersons. Journal of Marketing 48, 9-21.

11. Blau, G., 1999. Early-career job factors influencing the professional commitment of medical technologist. Academy of Management Journal 42, 687-695.

12. Boles, J.S., Wood, J.A., Johnson, J., 2003.Interrelationships of role conflict, role ambiguity, and work-family conflict with different factors of job satisfaction and the moderating effects of gender. Journal of Personal Selling \& Sales Management 23 (2), 99-113.

13. Brown, S., Peterson, R.A., 1993. Antecedents and consequences of salesperson job satisfaction: meta-analysis and assessment of causal effects. Journal of Marketing Research 30 (1), 63-77.

14. Brownell, J., 1990. The symbolic/culture approach: managing transition in the service industry. International Journal of Hospitality Management 9 (3), 191-205.

15. Brymer, R.A., Perrewe', P.L., Johns, T.R., 1991. Managerial job stress in the hotel industry. International Journal of Hospitality Management 10 (1), 47-58.

16. Bruck, C.S., Allen, T.D., Spector, P.E., 2002. The relation between work-family 


\section{Macrothink}

International Journal of Learning \& Development

ISSN 2164-4063

2014, Vol. 4, No. 2

conflict and job satisfaction: a finer-grained analysis. Journal of Vocational Behavior $60,336-353$.

17. Baron, R. M., \& Kenny, D. (1986).The moderator-mediator variable distinction in social psychological research.Journal of Personality and Social Psychology, 51, 1173-1182.

18. Blau, P. (1964). Exchange and power in social life.New York: Wiley.

19. Brown, S. P. (1996). A meta-analysis and review of organizational research on job involvement.Psychological Bulletin, 120, 235-255.

20. Buchanan, B. (1964). Building organizational commitment: The socialization of managers in work organizations.Administrative Science Quarterly, 19, 533-546.

21. Babin, B.J. and Boles, J.S. (1996), "The effects of perceived co-worker involvement and supervisor support on service provider role stress, performance, and job satisfaction", Journal of Retailing, Vol. 72 No. 1, pp. 57-75.

22. Baugh, S.G. and Roberts, R.M. (1994), "Professional and organizational commitment among engineer: conflicting or complementary?" IEEE Transactions on Engineering Management, Vol. 41 No. 2, pp. 108-14.

23. Bedeian, A.G. and Armenakis, A.A. (1981), "A path-analytic study of the consequences of role conflict and ambiguity", Academy of Management Journal, Vol. 24, June, pp. 417-24.

24. Bluedorn, A.C. (1982), "A unified model of turnover from organizations", Human Relations, pp. 135-53.

25. Brown, S.P. and Peterson, R.A. (1993), "Antecedents and consequences of salesperson job satisfaction: meta-analysis and assessment of causal effects", Journal of Marketing Research, pp. 63-77.

26. Brown, S.P. and Peterson, R.A. (1994), "The effect of effort on sales performance and job satisfaction", Journal of Marketing, pp. 70-80.

27. Carlson, D. S., \&Perrewe, P. L. (1999).The role of social support in the stressor-strain relationship: An examination of work-family conflict.Journal of Mangement, 25, 513-540.

28. Chen, Z., Lam, W., \&Zhong, J. A. (2007). Leader-member exchange and member performance: A new look at individual-level negative feedback-seeking behavior and team-level empowerment climate. Journal of Applied Psychology, 92, 202-212.

29. Cropanzano, R., \& Mitchell, M. S. (2005). Social Exchange Theory: An Interdisciplinary Review.Journal of Management, 31, 874-900.

30. Chen, C.F., 2006. Job satisfaction, organizational commitment, and flight attendants' turnover intentions: a note.Journal of Air Transport Management 12, 274e276. 


\section{Macrothink}

International Journal of Learning \& Development

ISSN 2164-4063

2014, Vol. 4, No. 2

31. Churchill, G.A. Jr, Ford, N.M. and Walker, O.C. Jr (1974), "Measuring the job satisfaction of industrial salesmen", Journal of Marketing Research, pp. 254-60.

32. Dewe, P.J. and Guest, D.E. (1990), "Methods of coping with stress at work: a conceptual analysis and empirical study of coping issues", Journal of Organizational Behavior, Vol. 11, pp. 135-50.

33. Dubinsky, A.J. and Mattson, B.E. (1979), "Consequences of role conflict and ambiguity experienced by retail salespeople", Journal of Retailing, Vol. 55, Winter, pp. 70-86.

34. Dubinsky, A.J., Michaels, R.E., Kotabe, M., Lim, C.U. and Moon, H.C. (1992), "Influence of role stress on industrial salespeople's work outcomes in the United States, Japan, and Korea", Journal of International Business Studies, Vol. 23 No. 1, Spring, pp. 77-90.

35. Dann, D., 1990. The nature of managerial work in the hospitality industry. InternationalJournal of Hospitality Management 9 (4), 319-334.

36. Dansereau, F., Graen, G., \&Haga, W. J. (1975).A vertical dyad linkage approach to leadership within formal organizations: a longitudinal investigation of the role making process. Organizational Behavior and Human Performance, 13, 46-78.

37. Deluga, R. J. (1998). Leader-member exchange quality and effectiveness ratings. Group andOrganization Management, 23, 189-216.

38. Dienesch, R. M., \&Liden, R. C. (1986).Leader-member exchange model of leadership: a critique and further development. Academy of Management Review, 11(3), 618-634.

39. Dunning, D., Heath, C., \&Suls, J. M. (2004).Flawed self-assessment: Implications for health, education, and the workplace. Psychological Science in the Public Interest, 5, 69-106.

40. Downs, C.W., Downs, A., Potvin, T., Varona, F., Gribas, J.S. and Ticehurst, W. (1995), “A cross-cultural comparison of relationships between organizational commitment and organizational communication", paper presented at the International CommunicationAssociation Convention, Albuquerque, New Mexico, May.

41. Eagly, A.H., 1987.Sex Differences in Social Behavior: A Social-Role Interpretation.Hillsdale, $\mathrm{NJ}$.

42. Edwards, J.R., Bagozzi, R.P., 2000. On the nature and direction of relationshipsbetween constructs and measures. Psychological Methods 5, 155-174.

43. Eckles, R.W. (1987), "Stress - making friends with the enemy", Business Horizons, Vol. 30 No. 2, pp. $74-8$.

44. Edwards, J.R. (1992), "A cybernetic theory of stress, coping, and well-being in organizations", Academy of Management Review, Vol. 17, pp. 238-74. 


\section{I Macrothink}

International Journal of Learning \& Development

ISSN 2164-4063

45. Faulkner, B., Patiar, A., 1997. Workplace induced stress among operational staff inthe hotel industry. International Journal of Hospitality Management 16 (1), 99-117.

46. Fielden, S.L., Davidson, M.J., 2001. Stress and gender in unemployed female andmale managers. Applied Psychology 50 (2), 305-334.

47. Fisher, C.D., Gitelson, R., 1983. A meta-analysis of the correlates of role conflict andambiguity. Journal of Applied Psychology 68 (2), 320-333.

48. Ford, N.M., Walker, O.C. and Churchill, G.A. Jr (1975), "Expectation-specific measures of the inter sender conflict and role ambiguity experienced by industrial salesmen", Journal of Business Research, Vol. 3, pp. 95-112.

49. Fry, L.W., Futrell, C.M., Parasuraman, A. and Chmielewski, M.A. (1986), “An analysis of alternative causal models of salesperson role perceptions and work related attitudes", Journal of Marketing Research, Vol. 23, pp. 153-63.

50. Fogarty, T.J., 1996. Gender differences in the perception of the work environmentwithin large international accounting firms.Managerial Auditing Journal $11(2), 10-19$.

51. Ghiselli, R., La Lopa, J.M., Bai, B., 2001. Job satisfaction. Life satisfaction \& turnoverintent of food service managers. Cornell Hotel \& Restaurant AdministrationQuarterly 42, 28-37.

52. Gianakos, I., 2001. Predictors of career decision-making self-efficacy.Journal ofCareer Assessment 9 (2), 101-114.

53. Gill, A.S., Flaschner, A.B., Shachar, M., 2006.Mitigating stress and burnout byimplementing transformational-leadership. International Journal of ContemporaryHospitality Management 18 (6/7), 469-482.

54. Grandey, A.A., Cordeiro, B.L., Crouter, A.C., 2005.A longitudinal and multi-source test of the workefamily conflict and job satisfaction relationship.Journal of Occupational and Organizational Psychology 78, 305e323.

55. Hales, C., Nightingale, M., 1986. What are unit managers supposed to do? InternationalJournal of Hospitality Management 5 (1), 3-11.

56. Hamner, W.C., Tosi, H.L., 1974. Relationship of role conflict and role ambiguity to jobinvolvement measures. Journal of Applied Psychology 59 (4), 497-499.

57. Hartline, M.D., Ferrell, O.C., 1996. The management of customer-contact serviceemployees: an empirical investigation. Journal of Marketing 60, 52-70.

58. Jackson, S.E., Joshi, A., Erhardt, N.L., 2003. Recent research on team and organizationaldiversity: SWOT analysis and implications.Journal of Management $26,801-830$.

59. Jackson, S.E., Schuler, R.S., 1985. Ameta-analysis and conceptual critique of 


\section{Macrothink}

International Journal of Learning \& Development

ISSN 2164-4063

2014, Vol. 4, No. 2

researchon role ambiguity and role conflict in work settings. Organizational Behavior \&Human Decision Processes 36 (1), 16-78.

60. Jaworski, B.J., Kohli, A.K., 1993. Market orientation: antecedents and consequences.Journal of Marketing 57, 53e 70.

61. Kahn, R., Wolfe, D., Quinn, R., Snoek, J., Rosenthal, R., 1964. Organizational Stress:Studies on Role Conflict and Ambiguity. John Wiley, New York.

62. Karatepe, O.M., Yavas, U., Babakus, E., Avci, T., 2006. Does gender moderate theeffects of role stress in frontline service jobs? Journal of Business Research 59(10-11), 1087-1093.

63. Leigh, J.H., Lucas Jr., G.H.,Woodman, R.W., 1988. Effects of perceived organizationalfactors on role stress-job attitude relationships. Journal of Management $14(1), 41-58$.

64. Lusch, R.F., Jaworski, B.J., 1991. Management controls, role stress, and retail storemanager performance. Journal of Retailing 67 (4), 397-419.

65. Miles, R.H., Perreault Jr., W.D., 1976. Organizational role conflict: its antecedentsand consequences. Organizational Behavior and Human Performance 17, 19-44.

66. Mukherjee, A., Malhotra, N., 2006. Does role clarity explain employee-perceivedservice quality? A study of antecedents and consequences in call centres.International Journal of Service Industry Management 17 (5), 444-473.

67. Netemeyer, R.G., Maxham III, J.G., Pullig, C., 2005. Conflicts in the workefamily interface: links to job stress, customer service employee performance, and customer purchase. Journal of Marketing 69, 130e143.

68. Ortqvist, D., Wincent, J., 2006. Prominent consequences of role stress: a metaanalyticreview. International Journal of Stress Management 13 (4), 399-422.

69. Podsakoff, P.M., MacKenzie, S.B., Lee, J.Y., Podsakoff, N.P., 2003.Common methodbiases in behavioral research: a critical review of the literature and recommendedremedies. Journal of Applied Psychology 88, 879-903.

70. Ptacek, J.T., Smith, R., Dodge, K.L., 1994. Gender differences in coping with stress:when stressor and appraisal do not differ. Personality and Social PsychologyBulletin 20, 421-430.

71. Rizzo, J.R., House, R.J., Lirtzman, S.I., 1970. Role conflict and ambiguity in complexorganizations. Administrative Science Quarterly 15 (2), 150-163.

72. Ross, L.E., Boles, J.S., 1994. Exploring the influence of workplace relationships onwork-related attitudes and behaviors in the hospitality work environment.International Journal of Hospitality Management 13 (2), 155-171.

73. Schwepker, C.H., Hartline, M.D., 2005. Managing the ethical climate of 
customercontactservice employees. Journal of Service Research 7 (4), 377-397.

74. Sekaran, U., 1983. Methodological and theoretical issues and advancements incross-cultural research. Journal of International Business Studies 14, 61-73.

75. Spector, P.E., 1985. Measurement of human service staff satisfaction: developmentof the job satisfaction survey.American Journal of Community Psychology 13,693-713.

76. Schleicher, D.J., Watt, J.D., Greguras, G.J., 2004. Reexamining the job satisfaction-performance relationship: the complexity of attitudes. Journal of Applied

77. Psychology 89, 165e177.

78. Takalkar, P., Coovert, M.D., 1994. The dimensionality of job satisfaction in India.Applied Psychology: An International Review 43, 415-426.

79. Tubre, T.C., Collins, J.M., 2000. Jackson and Schuler (1985) revisited: a meta-analysisof the relationships between role ambiguity, role conflict, and job performance.Journal of Management 26, 155-169.

80. Weatherly, K.A., Tansik, D.A., 1993. Tactics used by customer-contact workers:effects of role stress, boundary spanning and control. International Journal ofService Industry Management 4 (3), 4-17.

81. Westman,M., 1992. Moderating effect of decision latitude on stress-strain relationship:does organizational level matter? Journal of Organizational Behavior 13(7), 713-722.

82. Wetzels, M., de Ruyter, K., Lemmink, J., 1999.Role stress in after-sales servicemanagement. Journal of Service Research 2 (1), 50-67.

83. Williams, C., 2003. Sky service: the demands of emotional labour in the airline industry. Gender, Work and Organization 10, 513e550

84. Zohar, D., 1994. Analysis of job stress profile in the hotel industry. InternationalJournal of Hospitality Management 13 (3), 219-231 